\title{
扇形集束磁場に関する考察
}

\section{On the Sector Type Magnetic Focusing Field}

\author{
門田憲章・石田精一・金川哲夫* \\ Noriaki Kadota, Seiichi Ishida, Tetsuo Kanagawa
}

(1958年 9 月15日受理)

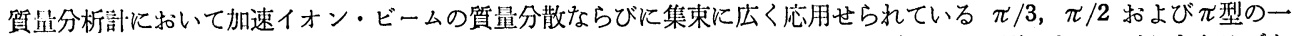
次単集束形式の朋形䂭場について，イオン・ビームに厚みがなくひろがりのみあるばあいと，曆みむひろがりもあるばあ いとについてコレクタ一面上に得られる像の位置を要素的に分解して計算し，それらの個別的な結果を綜合して総像门を 純幾何学的に求めた。その結果イオン源の最終巾の決定等に関し数量的な知見を得ることができた。
\end{abstract}

\section{I. 緒言}

荷電粘子線の質量分散ならびに集束については Heuneberg, ${ }^{1)}$ Herzog, ${ }^{2)}$ Mattauch $^{3)}$ 等によって正 統的なイオン幾何光学的取扱いが集成せられており， 質量分析のための集束条件については基楼的にはるは やほとんど論じつくされた観があるのであるが，細か い点に考察を進めるとまだ明らかにされていない点も いくつか存在する。集束磁場の理想は言うまでもなく 少なくとも理論的には無収差であることであり，その ような見地に立って考察を進めれば一応 Kerwin ${ }^{4)}$ 場 には誰しも想到するところであろうが，实際に装置と しての質量分析計を通観すると，他の原理によるもの は別として現在国内に設置せられている質量分析計は すべて羽形磁場を有するものである。占 したがって， 現在の段階では一次単集束磁場についてイオン・ビー ムの集束を吟味することもあながち無意味ではないと 考えられる。

本稿に打いて対象とするのは一次巣集束型質量分析 計の構成上存在する各種の収差のらち, 厚みがなくひ ろがりのみを持つイオン・ビームが理想的すなわち完 全に幾何光学的行動を行うばあいについてイオンの偏 向角と偏向半径のみに関係しイオン・ビームのひろが りの角度によって定められる幾何学的収差をはじめに 取扱い，つぎにイオン・ビームに愿みのある実際の装 置により近いばあいについてコレクター上に得られる 像巾を考察する。考察の対象となる磁場は $\pi / 3-, \pi / 2-$ および $\pi$ - 型限定し，またイオン源, 偏向磁場执よ びコレクター・スリットの相対位置に関しては対称型

* 京都大学工学部然料化学教室（京都市左京区吉田本町） Department of Fuel Chemistry of the Engineering Faculty of Kyoto University (Yoshida Honmachi, Sakyo ward, Kyoto, Japan).
Barber ${ }^{6)}$ 配置であることを前提とし，磁場境界は理想 的であるかあるいは Nier 近似が綮密に成立するもの として取扱いを進める。

\section{II. 記号の規約}

イオン・ビームには愿みがありひろがりがあるので, 射出イオン・ビームならびにその到迕点について各種 の組合わせが考えられ，いちいち記述するのは煩雑で あり，むしろ記号的に表現する方が便利であるので次 のように統一的汇記昂を規約することにする。

$\mathrm{O} ：$ イオン源スリット最外端（偏向中心から見て） から射出せられるイオン・ビーム

$\mathrm{O}^{\prime}$ : このイオン・ビームがコレクター面上に到達す る点の位置

C：イオン源中心から射出世られるイオン・ビーム

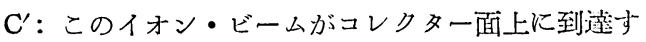
る点の位置

I：イオン源スリット最内端から射出せられるイオ ン・ビーム

$I^{\prime}$ ：このイオン・ビームがコレクター面上に到達す る点の位置

これらの記昼についてさらにイオン・ビームのひろ がり角，スリット巾等イオン・ビームの性格を表示す るため次のように添字を用いる。

$\mathrm{O}$, or $\mathrm{C}$, or I (o..), or ( \pm 0$)$ ：射出イオン・ビーム の中心束 (....), 外侧へのひろがりが中心束に対

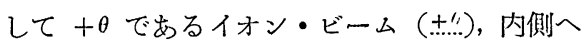
のひろがりが $-\theta$ であるイオン・ビーム $(-. . . \prime)$.

O or I $\left(\begin{array}{l}0 \\ n\end{array}\right)$ or $\left(\begin{array}{c} \pm 0 \\ n\end{array}\right)$ : 射出イオン・ビームの厚みが 偏向半径 $r$ の $2 / n(n$ : 愿及係数)であることを 示す。したがって中心イオン・ビームは C $\left(\begin{array}{c}0 \\ \infty\end{array}\right)$, C ( $\left.\begin{array}{c} \pm \theta \\ \infty\end{array}\right)$ である。 
例. $\mathrm{O}\left(\begin{array}{c}+\theta \\ n\end{array}\right)$ : 厚み係数 $n$ のスリットの最外端から 外側へ $\theta$ の角度で射出せられるイオン・ビームで, そのコレクター上の結像点である。

つぎにコレクター上にあらわれる像について次の記 号を用いる。

$\mathrm{S} ：$ コレター上に出現する像のコレクター中心か らはかった距離。

さらにこのSの性格を表示するため次のように添字 を用いる。

$\mathrm{S}_{\pi / 3}$ or $\pi / 2$ or $\pi(\cdots \cdots \cdots . . .$.$) : イオン偏向角が \pi / 3, \pi / 2$ あるいは $\pi$ であることを示す。

S.O or C or I (……:) : O ( ……), C (……..) あるいは I (…….) によって生じる像巾.

$\mathrm{S}$. O or I $\left(\begin{array}{c} \pm \theta \\ n\end{array}\right): \mathrm{O}\left(\begin{array}{c}0 \\ n\end{array}\right),\left(\begin{array}{c} \pm \theta \\ n\end{array}\right)$ または I $\left(\begin{array}{c}0 \\ n\end{array}\right),\left(\begin{array}{c} \pm \theta \\ n\end{array}\right)$ によ って生ずる像巾.

S.C. $\left(\begin{array}{c} \pm \theta \\ \infty\end{array}\right): \mathrm{C}\left(\begin{array}{c} \pm \theta \\ \infty\end{array}\right)$ とよって生ずる像巾.

$\mathrm{S}$ O $\mathrm{I} \mathrm{I}\left(\begin{array}{l}0 \\ n\end{array}\right) \quad: \mathrm{O}\left(\begin{array}{l}0 \\ n\end{array}\right)$ と $\mathrm{I}\left(\begin{array}{l}0 \\ n\end{array}\right)$ との平行イオン・ビ 一ムによって生ずる像巾.

ऽ：すべてのSの币を総合してあらわれる最大の 像巾.コレクター中心を原点としたばあい外側へ の像のひろがりを $\mathrm{S}+$, 内側へのひろがりを $\mathrm{S}-$
とすると，

$$
\mathfrak{S}=\mathrm{S}^{+} \text {max }+\left|\mathrm{S}-{ }_{\text {max }}\right|
$$

で与えられる。

例. $\mathrm{S}_{\pi}^{0}\left(\begin{array}{c} \pm \theta \\ n\end{array}\right): \pi$-磁揚に打いて $\mathrm{O}\left(\begin{array}{c} \pm \theta \\ n\end{array}\right)$ によって生ず る像巾

\section{1. $\mathrm{S}_{\pi / 3}^{\mathrm{C}}\left(\begin{array}{c} \pm \theta \\ \infty\end{array}\right)$ および $\widetilde{\sigma}_{\pi / 3}\left(\begin{array}{c} \pm \theta \\ . \infty\end{array}\right)$}

第 1 図に拈いて明らかなよ5に，紨面に垂直方向に 巾をもつイオン・ビームのうち, 磁場に直角に入射する $\mathrm{C}\left(\begin{array}{l}0 \\ \infty\end{array}\right)$ のコレクター上の像位置 $\mathrm{C}^{\prime}\left(\begin{array}{l}0 \\ \infty\end{array}\right)$ と, $\mathrm{C}\left(\begin{array}{l}0 \\ \infty\end{array}\right)$ に対し $+\theta$ 㧊よび $-\theta$ の開きをるって射出されるビームの $\mathrm{C}\left(\begin{array}{c}+\theta \\ \infty\end{array}\right)$ および $\mathrm{C}\left(\begin{array}{c}-\theta \\ \infty\end{array}\right)$ のそれぞれの像位置 $\mathrm{C}\left(\begin{array}{c}+\theta \\ \infty\end{array}\right)$ お よび $\mathrm{C}^{\prime}\left(\begin{array}{c}-\theta \\ \infty\end{array}\right)$ とがイオン像の巾を与えることは周知の と打りである。

この像巾を求める手順は解析幾何学の問題として取 扱らことができる。座標を図のようにとると，開き角． $+\theta$ のビームは

$$
\boldsymbol{y}=\boldsymbol{x} \cdot \tan \theta+\boldsymbol{r}(2+\sqrt{3} \tan \theta)
$$

で表わされ，A点で磁場に入射しその曲率中心 $\mathrm{O}^{\prime}+\left(\boldsymbol{x}^{\prime}\right.$, $\left.\boldsymbol{y}^{\prime}\right)$ は

$$
x^{\prime}=r \sin \theta, y^{\prime}=r(2+\sqrt{3} \tan \theta-\cos \theta)
$$

となる。このビームは $y=\frac{1}{\sqrt{3}} x+r$ として表わされ

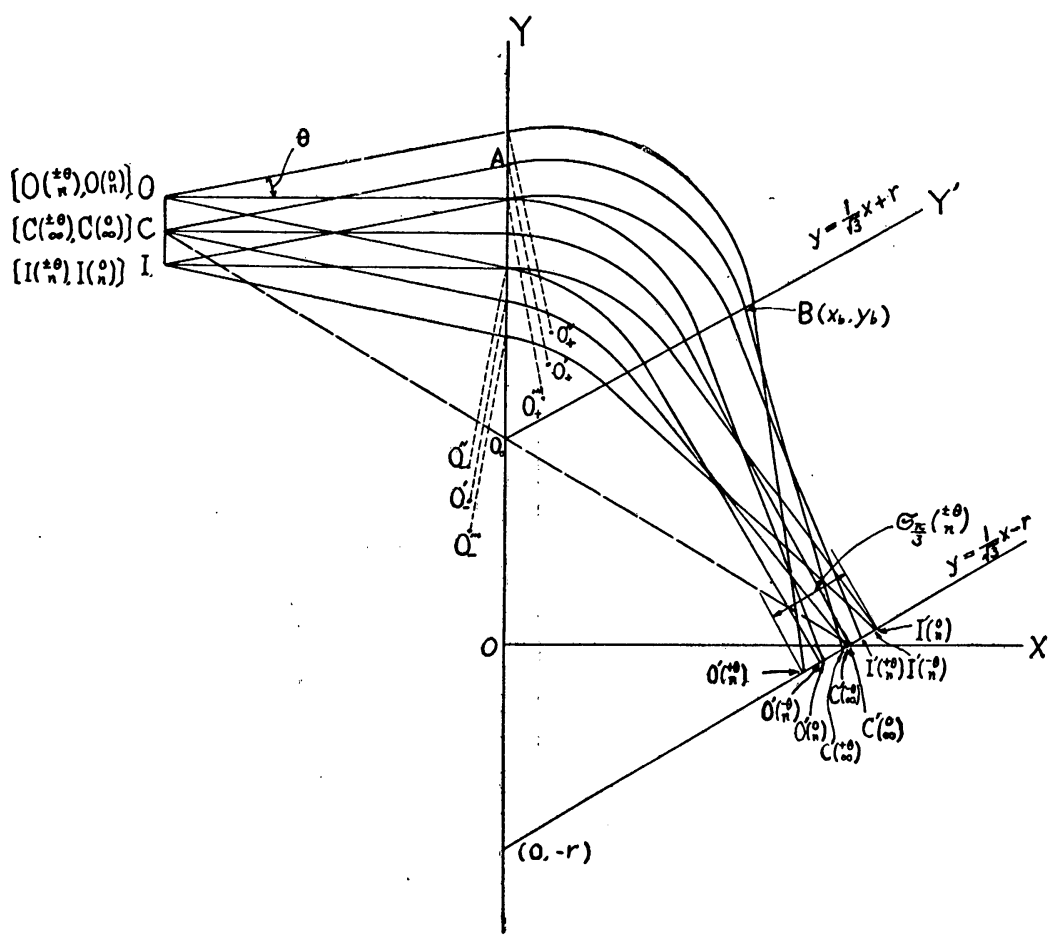




\section{.}

$\mathrm{B}\left(x_{b}, y_{b}\right)$ 点で磁場境界 $\mathrm{O}_{0} \mathrm{Y}^{\prime}$ を出てコレクター・プ レートすなわち $y=\sqrt{\frac{1}{3}} x-r$ 直線上に $\mathrm{C}^{\prime}\left(\begin{array}{l}+1 \\ \infty\end{array}\right)$ なる 像を結ぶことになる。すると， $\boldsymbol{x}_{b}, \boldsymbol{y}_{b}$ は

$$
\begin{aligned}
x_{b} & =\frac{\sqrt{3}}{4}\left\{\sqrt{3} x^{\prime}-r+y^{\prime}\right. \\
& \left.+\sqrt{r^{2}+6 r y^{\prime}-3 y^{\prime 2}-2 \sqrt{3}} \overline{x^{\prime}\left(r-y^{\prime}\right)-x^{\prime 2}}\right\} \\
y_{b} & =\frac{1}{4}\left\{\sqrt{3} x^{\prime}+3 r+y^{\prime}\right. \\
& \left.+\sqrt{\boldsymbol{r}^{2}+6 r y^{\prime}-3 y^{\prime 2}-2 \sqrt{3} x^{\prime}\left(r-y^{\prime}\right)-x^{\prime 2}}\right\}
\end{aligned}
$$

であり, $\mathrm{C}^{\prime}\left(\begin{array}{c}+\theta \\ \infty\end{array}\right)$ の座標 $(\boldsymbol{x}, \boldsymbol{y})$ は

$$
\begin{aligned}
& x=\sqrt{ } 3\left\{\frac{r^{2}+\left(\boldsymbol{r}+\boldsymbol{y}^{\prime}\right)\left(\boldsymbol{y}_{b}-\boldsymbol{y}^{\prime}\right)+\boldsymbol{x}^{\prime}\left(\boldsymbol{x}_{b}-\boldsymbol{x}^{\prime}\right)}{\sqrt{3}\left(\boldsymbol{x}_{b}-\boldsymbol{x}^{\prime}\right)+\left(\boldsymbol{y}_{b}-\boldsymbol{y}^{\prime}\right)}\right\} \\
& \boldsymbol{y}=\frac{\boldsymbol{r}^{2}+\left(\boldsymbol{r}+\boldsymbol{y}^{\prime}\right)\left(\boldsymbol{y}_{b}-\boldsymbol{y}^{\prime}\right)+\boldsymbol{x}^{\prime}\left(\boldsymbol{x}_{b}-\boldsymbol{x}^{\prime}\right)}{\sqrt{3\left(\boldsymbol{x}_{b}-\boldsymbol{x}^{\prime}\right)+\left(\boldsymbol{y}_{b}-\boldsymbol{y}^{\prime}\right)}-r}
\end{aligned}
$$

となる。一方 $\overline{\mathrm{C}^{\prime}\left(\begin{array}{c}+\theta \\ \infty\end{array}\right) \mathrm{C}^{\prime}\left(\begin{array}{l}0 \\ \infty\end{array}\right)}=2 \boldsymbol{y}$ であるため, (4)式の $\boldsymbol{y}$ に $\left(\boldsymbol{x}^{\prime}, \boldsymbol{y}^{\prime}\right) ;\left(\boldsymbol{x}_{b}, \boldsymbol{y}_{b}\right)$ を代入し $\mathrm{C}\left(\begin{array}{c}-1 / \\ \infty\end{array}\right)$ をもあわせ て考えると S は次のようになる。

$$
\begin{aligned}
\mathrm{S}_{\pi / 3}^{\mathrm{C}}\left(\begin{array}{c} 
\pm \theta \\
\omega
\end{array}\right) & =\frac{r}{2}\left[\frac{4-(\varphi+\sqrt{3})^{2}-2 \sqrt{3}(\varphi+\sqrt{3})}{\sqrt{1-\phi^{2}-2 \sqrt{3} \boldsymbol{D}}}\right. \\
& \left.+\sqrt{3} \tan \theta-2 \sin \left(\frac{\pi}{6}-\theta\right)-1\right] \\
\text { ここに } & =3 \tan \theta-2 \sin \left(\frac{\pi}{3}+\theta\right)
\end{aligned}
$$

である。なお，この像巾の正負は四からも分るように 正のときは $\mathrm{C}^{\prime}\left(\begin{array}{l}0 \\ 0\end{array}\right)$ の外側に, 負のときは内側に結像す ることを示している。 $\theta$ にいろいろの值を入れて計算 してみると (第 4 図), $\mathrm{C}^{\prime}\left(\begin{array}{c}+ \\ \infty\end{array}\right), \mathrm{C}^{\prime}\left(\begin{array}{c}- \\ \infty\end{array}\right)$ いずれも内侧

にありその上，

$$
\left|\mathrm{S}_{\pi / 3}\left(\begin{array}{c}
+\theta \\
\infty
\end{array}\right)\right| \geqq\left|\mathrm{SC}_{\pi / 3}\left(\begin{array}{c}
-\theta \\
\infty
\end{array}\right)\right|
$$

であるため,このばあいの的 $\left|\mathrm{S}_{\pi / 3}\left(\begin{array}{l}+ \\ \infty_{\infty}\end{array}\right)\right|$ のみを計 算すればよいことになる。すなわち，

$$
\widetilde{S}_{\pi / 3}\left(\begin{array}{c} 
\pm \prime \\
\infty
\end{array}\right)=\left|S^{C} \pi / 3\left(\begin{array}{c}
+6 \\
\infty
\end{array}\right)\right|
$$

のように表わされる。

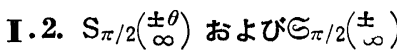

座標を第 2 四のよ5にとって $\pi / 3$ 型と同様に考え のることができる。このばあいは計算は簡単で $\mathrm{C}\left(\begin{array}{c}+1, \\ \infty\end{array}\right)$ ビームは

$$
y=x \tan \theta+r(2+\tan \theta)
$$

として表わされ，その曲率中心 $\mathrm{O}^{\prime}+\left(\boldsymbol{x}^{\prime}, \boldsymbol{y}^{\prime}\right)$ は

$$
x^{\prime}=r \sin \theta, \quad y^{\prime}=r(2+\tan \theta-\cos \theta)
$$

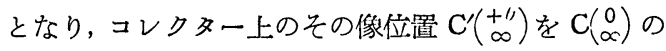
位置 $\mathrm{C}^{\prime}\left(\begin{array}{l}0 \\ \infty\end{array}\right)$ の座標 $(\boldsymbol{r}, \mathrm{O})$ から考光ると, このばあい の像巾は， $\mathrm{C}\left(\begin{array}{c}-1 \\ \infty\end{array}\right)$ をるともに考えに入れると，

$$
\begin{aligned}
& \mathrm{SC}_{\pi / 2}\left( \pm^{\prime}\right) \\
& =r\left[\sin \theta+\frac{1-(2-t)(1-t)}{(2-t) t}-1\right]
\end{aligned}
$$

となる。ここに

$$
t=\cos \theta-\tan \theta
$$

である。この結果は第 4 四に示されている。この像巾 の正負の関係は $\pi / 3$ - 型のときと同一で，その上

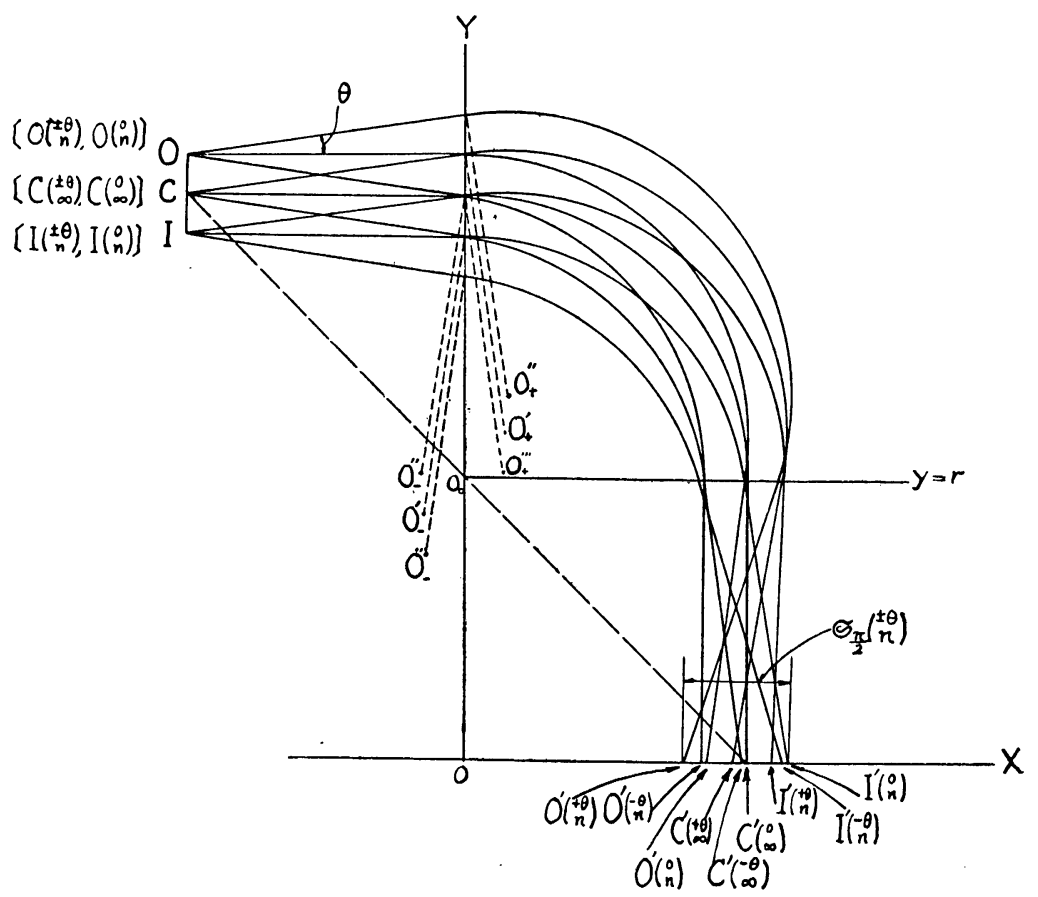

第 2 図 $\pi / 2$ - 型に括ける像幅 


$$
\left|\mathrm{S}_{\pi / 2}\left(\begin{array}{c}
+\theta \\
\infty
\end{array}\right)\right| \geqq\left|\mathrm{S}_{\pi / 2}\left(\begin{array}{c}
-\theta \\
\infty
\end{array}\right)\right|
$$

であるため,このばあいも，

$$
\widetilde{S}_{\pi / 2}\left(\begin{array}{c} 
\pm \theta \\
\infty
\end{array}\right)=\left|\mathrm{SC}_{\pi / 2}\left(\begin{array}{c}
+\theta \\
\infty
\end{array}\right)\right|
$$

として表わされる。

\section{I.3. $\mathbf{S}_{\pi}^{\mathrm{C}}\left(\begin{array}{c} \pm \theta \\ \omega\end{array}\right)$ および $\mathfrak{S}_{\pi}\left(\begin{array}{l} \pm \theta \\ \omega\end{array}\right)$}

第 3 困に示されているように座標をえらぶこととし， $\mathrm{C}\left(\begin{array}{l}0 \\ \infty\end{array}\right), \mathrm{C}\left(\begin{array}{c}+\theta \\ \infty\end{array}\right)$ および $\mathrm{C}\left(\begin{array}{c}-\theta \\ \infty\end{array}\right)$ の 3 本のビームのコレク
を導入するかということであるが，これには前にも記 したように $n$ なる厚み係数の形で導入するのがもっ とも取扱いが便利である。実用せられている質量分析 計を考えると，通常 $n=500 \sim 5,000$ でこれは $r=180$ $\mathrm{mm}$ としてイオン源出ロスリット巾 $0.007 \sim 0.7 \mathrm{~mm}$ に相当するわけで，計算も大体この範囲について行え ばよいことになる。

このよ5に厚みを考慮に入れた計算では, 中心ビー

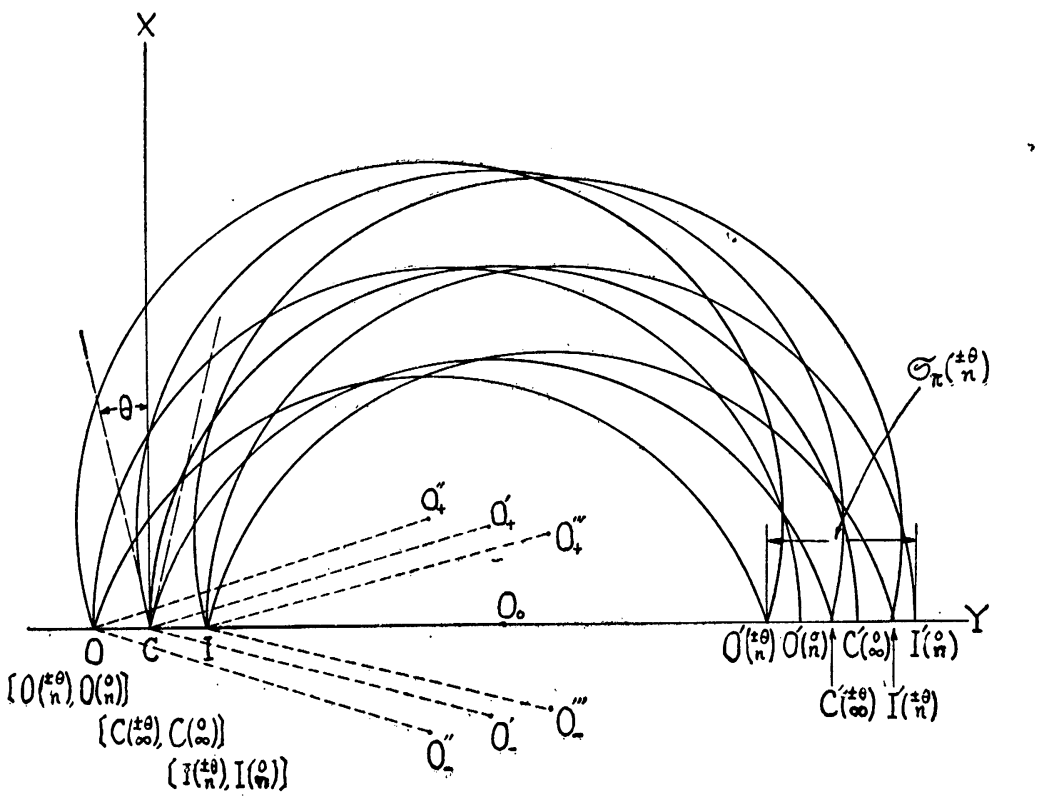

第3 図 $\pi$ - 型に拈ける像幅

ター上の結像位置を考えると, 当然のことではあるが 後者の 2 本のビームの像位置 $\mathrm{C}^{\prime}\left(\begin{array}{c}+\theta \\ \infty\end{array}\right)$ と $\mathrm{C}^{\prime}\left(\begin{array}{c}-\theta \\ \infty\end{array}\right)$ とは 一致し $2 r \cos \theta$ で表わされる。一方 $\mathrm{C}^{\prime}\left(\begin{array}{l}0 \\ \infty\end{array}\right)$ の座標は $(2 \boldsymbol{r}, 0)$ であるため, このばあいの像巾はよく知られて いるように,

$$
\Im_{\pi}\left(\begin{array}{c} 
\pm \theta \\
\infty
\end{array}\right)=\left|\mathrm{S}_{\pi}^{\mathrm{C}}\left(\begin{array}{c} 
\pm \theta \\
\infty
\end{array}\right)\right|=|-2 r(1-\cos \theta)| \quad(13)
$$
のよ5になる。 $\theta$ の各值に対する像巾は第 4 図にさき の両型のときとあわせ示されている。

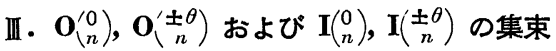

Iにおいては, ビームの厚みの極限として $n=\infty す$ なわち厚みを無視して、ひろがりだけをるったイオン ビームを考えたが, 実際には, かりに他の収差が無視 し得るほど小さいとしても, 少なくともイオン源の出 ロスリットのヤだけの厚みをるうたイオン・ビームを 考えなければならないので，Iの計算をさらに進めて この厚みをも計算に入れることにする。

ここに問題となるのは, いかなる形でビームの厚み
ム $\mathrm{C}\left(\begin{array}{l}0 \\ \propto\end{array}\right)$ に平行な $\mathrm{O}\left(\begin{array}{l}0 \\ n\end{array}\right), \mathrm{I}\left(\begin{array}{l}0 \\ n\end{array}\right)$ を含めて総計 9 本のビ 一ムについて，それぞれのコレクター一上の結像位置を すべて一応考光なければならないことになる。なお $\mathrm{C}\left(\begin{array}{l}0 \\ \infty\end{array}\right)$ と $\mathrm{C}\left(\begin{array}{c} \pm \theta \\ \infty\end{array}\right)$ の 3 本についてはすでに前章で計算 ずみであるので省略する。

III.1, $\mathbf{S}_{\pi / 3}^{\mathrm{O}, \mathrm{I}}\left(\begin{array}{l}0 \\ n\end{array}\right), \mathbf{S}_{\pi / 3}^{\mathrm{O}, \mathrm{I}}\left(\begin{array}{c} \pm \theta \\ n\end{array}\right)$ および $\mathfrak{S}_{\pi / 3}\left(\begin{array}{c} \pm \theta \\ n\end{array}\right)$

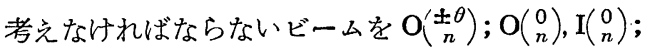
$\mathrm{I}\left(\begin{array}{c} \pm \theta \\ n\end{array}\right)$ の 3 群に分けて計算を進めることにする。

III. 1. a. $\mathrm{O}\left(\begin{array}{c} \pm \theta \\ n\end{array}\right)$ の集束

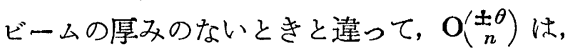
$y=x \tan \theta+r(2+1 / n+\sqrt{3} \tan \theta)$

で表わされることになり,このビームの曲率中心 $\mathrm{O}^{\prime \prime} \pm$ $\left(\boldsymbol{x}^{\prime \prime}, \boldsymbol{y}^{\prime \prime}\right)$ は,

$$
x^{\prime \prime}=r \sin \theta, \quad y^{\prime \prime}=r\left(2+\frac{1}{n}+\sqrt{3} \tan \theta-\cos \theta\right)
$$

となりささきと同様な計算を行い, 記昂も同じものを 
用いると, この 2 本のビームそれぞれによる像币は， $\mathrm{So}_{\pi / 3}\left(\begin{array}{c} \pm \theta \\ n\end{array}\right)=\frac{r}{2} \times$

$\left(\frac{4-\left\{\varphi+\sqrt{3}\left(1+\frac{1}{n}\right)\right\}^{2}-2 \sqrt{3}\left\{\varphi+\sqrt{3}\left(1+\frac{1}{n}\right)\right\}}{\sqrt{1-\varphi^{2}-2 \sqrt{3} \varphi-\frac{2 \sqrt{3}}{n}} \varphi-\frac{3}{n^{2}}(2 n+1)}\right.$

$\left.+\sqrt{3} \tan \theta-2 \sin \left(\frac{\pi}{6}-\theta\right)-\left(1-\frac{1}{n}\right)\right)$

(16)

となる。このばあいの符号の正負と像位置との関係も

さきと同様であり, かつまた

であるため,

$$
\left|\mathrm{S}_{\pi / 3}^{0}\left(\begin{array}{c}
+\theta \\
n
\end{array}\right)\right| \geqq\left|\mathrm{S}_{\pi / 3}^{0}\left(\begin{array}{c}
-\theta \\
n
\end{array}\right)\right|
$$

となる。

$$
\mathfrak{S}_{\pi / 3}^{0}\left(\begin{array}{c} 
\pm \theta \\
n
\end{array}\right)=\left|\mathrm{S}_{\pi / 3}^{0}\left(\begin{array}{c}
+(\prime \\
n
\end{array}\right)\right|
$$

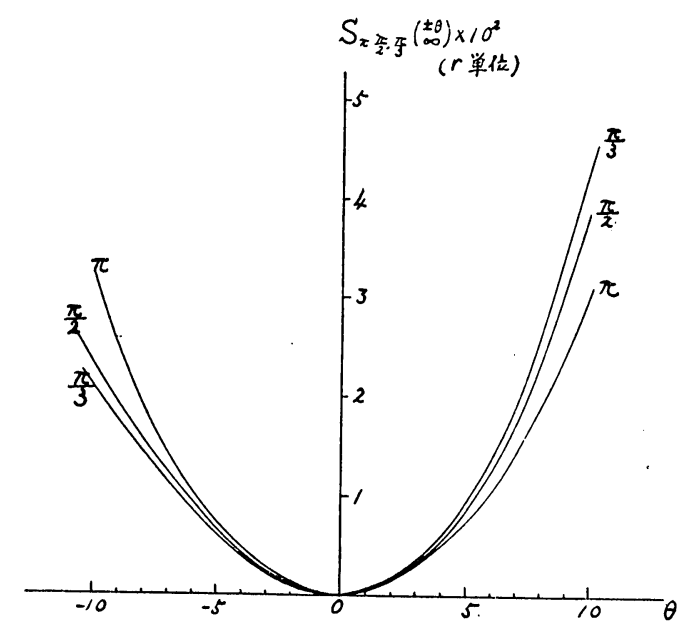

第 4 図 $\mathrm{n}=\infty$ のとさの $\theta$ と像幅の関係

II. 1. b. $\mathrm{O}\left(\begin{array}{l}0 \\ n\end{array}\right), \mathrm{I}\left(\begin{array}{l}0 \\ n\end{array}\right)$ の集束

この 2 本の平行ビームは

$$
y=r
$$

なる直線上で一度交わり，そののちふたたび離散して $\mathrm{C}\left(\begin{array}{l}0 \\ \infty\end{array}\right)$ の両側に結像し，それぞれの像巾は

$\mathrm{S}_{\pi / 3}^{0}\left(\begin{array}{l}0 \\ n\end{array}\right)=2 r\left[\frac{4 n^{2}+(2 n+1)\{\sqrt{(2 n+1)(2 n-1)}-3\}}{4 n \sqrt{(2 n+1)(2 n-1)}}-1\right]$

および

$\mathrm{S}_{\pi / 3}^{\mathrm{I}}\left(\begin{array}{l}0 \\ n\end{array}\right)=2 r\left[\frac{4 n^{2}+(2 n-1)\{\sqrt{(2 n+1)(2 n-1)}+3\}}{4 n \sqrt{(2 n+1)(2 n-1)}}-1\right]$

となり, $\mathrm{S}_{\pi / 3}^{0}\left(\begin{array}{l}0 \\ n\end{array}\right)<0, \mathrm{~S}_{\pi / 3}^{\mathrm{I}}\left(\begin{array}{l}0 \\ n\end{array}\right)>0$ であるため,

$$
\mathfrak{S}_{\pi / 3}^{\mathrm{O}, \mathrm{I}}\left(\begin{array}{l}
0 \\
n
\end{array}\right)=r\left[\frac{6}{\sqrt{(2 n+1)(2 n-1)}}-\frac{1}{n}\right] \quad \text { (21) }
$$

となる。これら 2 つ像をみると，nが小さいとき，
すなわちビームにかなりの厚みがあるときは，

$$
\left|\mathrm{S}_{\pi / 2}^{\mathrm{O}}\left(\begin{array}{l}
0 \\
n
\end{array}\right)\right|<\mathrm{S}_{\pi / 2}^{\mathrm{I}}\left(\begin{array}{l}
0 \\
n
\end{array}\right)
$$

であり， $\mathrm{O}^{\prime}\left(\begin{array}{l}0 \\ n\end{array}\right)$ の方が $\mathrm{I}^{\prime}\left(\begin{array}{l}0 \\ n\end{array}\right)$ より $\mathrm{C}^{\prime}\left(\begin{array}{l}0 \\ \infty\end{array}\right)$ 飞関して遠 くにあるが, $n$ が 500 以上では $\mathrm{C}^{\prime}\left(\begin{array}{l}0 \\ \infty\end{array}\right)$ の両侧対称位置 に来ることが分る。

\section{III.1.c. $\mathrm{I}\left(\begin{array}{c} \pm \theta \\ n\end{array}\right)$ の集束}

このビームは

$$
y=x \tan \theta+r\left(2-\frac{1}{n}+\sqrt{3} \tan \theta\right)
$$

で表わされ，その曲率中心 $\mathrm{O}_{ \pm}^{\prime \prime \prime}\left(\boldsymbol{x}^{\prime \prime \prime}, \boldsymbol{y}^{\prime \prime \prime}\right)$ は

$$
x^{\prime \prime \prime}=r \operatorname{rin} \theta, y^{\prime \prime \prime}=r\left(2-\frac{1}{n}+\sqrt{3} \tan \theta-\cos \theta\right)
$$

となり，さきと同じように，愿みがないげあいの $\pi / 3-$ 型に用いたと同じ記号を用いると，この 2 本のビーム のそれぞれによる像巾は，

$\mathrm{S}_{\pi / 3}^{\mathrm{I}}\left(\begin{array}{c} \pm \theta \\ n\end{array}\right)=$

$\frac{r}{2}\left(\frac{4-\left\{\varphi+\sqrt{3}\left(1-\frac{1}{n}\right)\right\}^{2}-2 \sqrt{3}\left\{\varphi+\sqrt{3}\left(1-\frac{1}{n}\right)\right\}}{\sqrt{1-\phi^{2}-2 \sqrt{3} \varphi+\frac{2 \sqrt{3}}{n} \varphi-\frac{3}{n^{2}}(2 n+1)}}\right.$

$\left.+\sqrt{3} \tan \theta-2 \sin \left(\frac{\pi}{6}-\theta\right)-\left(1+\frac{1}{n}\right)\right)$

(24)

となる。しかし，このばあいは， $\left.\mathrm{O}_{n}^{ \pm \theta}\right)$ のときと異な り, その結像位罭は開き角の $\theta$, および $n$ によって像 ウの正負捛よびその大小が变化する。しかし，これま での各ビームの結像位置の計算から， $\mathrm{I}\left(\begin{array}{c} \pm \theta \\ n\end{array}\right)$ による像 巾は $\theta=4^{0}$ までは総像巾のの外には出ないため, この 範囲では問題にしなくてもよいことになる。計算結果 から分るこは，もっとも内側に結像するビームは $\mathrm{O}\left(\begin{array}{c}+0 \\ n\end{array}\right)$ であり，もっとも外側に結像するビームは $\mathrm{I}\left(\begin{array}{l}0 \\ n\end{array}\right)$ であるということで，それゆえに総像巾は

$$
\mathfrak{S}_{\pi / 3}\left(\begin{array}{c} 
\pm \theta \\
n
\end{array}\right)=\left|\mathrm{S}_{\pi / 3}^{0}\left(\begin{array}{c}
+\theta \\
n
\end{array}\right)\right|+\mathrm{S}_{\pi / 3}^{\mathrm{I}}\left(\begin{array}{l}
0 \\
n
\end{array}\right)
$$

として与えられることになる。この結果は第 1 表に示 されている。表中符号の負は $\mathrm{S}_{\pi / 3}{ }^{0}\left(\begin{array}{c}+\theta \\ n\end{array}\right)$ を示し, 正は $\mathrm{S}_{\pi / 3}^{\mathrm{I}}\left(\begin{array}{l}0 \\ n\end{array}\right)$ を示してをり, 総像巾はこれら 2 数の絶対值 の和となる。

な拉，比較のため $n=\infty$ のばあいをも併記してある。

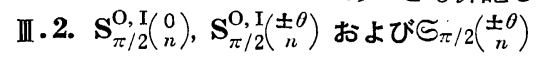

ビームの分け方は ${ }^{-}-\frac{\pi}{3}$-型のときと同様にして計算す る。

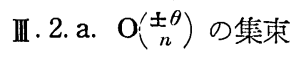

このビームは,

$$
y=x \tan \theta+r\left(2+\frac{1}{n}+\tan \theta\right)
$$

で表わされ，その曲率中心 $\mathrm{O}_{ \pm}^{\prime \prime}\left(\boldsymbol{x}^{\prime \prime}, \boldsymbol{y}^{\prime \prime}\right)$ は，

$$
x^{\prime \prime}=r \sin \theta, y^{\prime \prime}=r\left(2+\frac{1}{n}+\tan \theta-\cos \theta\right)(27)
$$


となる。このばあいも厚みのないときに用いたと同じ 記号によってそれぞれのビームによる像巾を求めると 次のようになる。

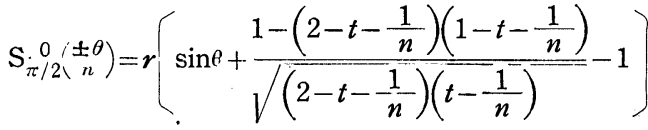

(28)

このばあいも, $\pi / 3$ - 型のときと同じく

$$
\left|\mathrm{S}_{\pi / 2}^{0}\left(\begin{array}{c}
+\theta \\
n
\end{array}\right)\right| \geqq\left|\mathrm{S}_{\pi / 2}^{0}\left(\begin{array}{c}
-\theta \\
n
\end{array}\right)\right|
$$

であるため,

$$
\widetilde{S}_{\pi / 2}^{0}\left(\begin{array}{c} 
\pm \theta \\
n
\end{array}\right)=\left|\mathrm{S}_{\pi / 2}^{0}\left(\begin{array}{c}
+\theta \\
n
\end{array}\right)\right|
$$

となる。

III. 2. b. $\mathrm{O}\left(\begin{array}{l}0 \\ n\end{array}\right), \mathrm{I}\left(\begin{array}{l}0 \\ n\end{array}\right)$ の集束

2 本の平行ビームは射出側磁場境界に打いて集束し， そののちふたたび離散し $\mathrm{C}^{\prime}\left(\begin{array}{l}0 \\ (\end{array}\right)$ の両側に結像するこ と,これまた $\pi / 3$ - 型のときと同様である。それぞれ のビームによる像巾は，

$$
\mathrm{S}_{\pi / 2}^{0}\left(\begin{array}{l}
0 \\
n
\end{array}\right)=\frac{r}{\sqrt{1-\frac{1}{n^{2}}}}\left(1-\frac{1}{n^{2}}-\frac{1}{n}\right) \quad \text { (30) }
$$

および

$$
\mathrm{S}_{\pi / 2}^{\mathrm{I}}\left(\begin{array}{l}
0 \\
n
\end{array}\right)=\frac{r}{\sqrt{1-\frac{1}{n^{2}}}}\left(1-\frac{1}{n^{2}}+\frac{1}{n}\right)
$$

であり, $\mathrm{S}_{\pi / 2}^{0}\left(\begin{array}{l}0 \\ n\end{array}\right)<0, \mathrm{~S}_{\pi / 2}^{\mathrm{I}}\left(\begin{array}{l}0 \\ n\end{array}\right)>0$ であるため総像巾は,

$$
\mathfrak{S}_{\pi / 2}^{\mathrm{O}, \mathrm{Y}}\left(\begin{array}{l}
0 \\
n
\end{array}\right)=\frac{2}{\sqrt{1-\frac{1}{n^{2}}}} \cdot \frac{r}{n}
$$

すなわち, ビームの厚さの $\frac{1}{\sqrt{1-\frac{1}{n^{2}}}}$ 倍となる。さら に,

$$
\left|\mathrm{S}_{\pi / 2}^{0}\left(\begin{array}{l}
0 \\
n
\end{array}\right)\right| \geqq \mathrm{S}_{\pi / 2}^{\mathrm{I}}\left(\begin{array}{l}
0 \\
n
\end{array}\right)
$$

であるため、ビームの厚みがかなりあるときには， $\mathrm{O}^{\prime}\left(\begin{array}{l}0 \\ n\end{array}\right)$ の方が $\mathrm{C}^{\prime}\left(\begin{array}{l}0 \\ \infty\end{array}\right)$ に対し $\mathrm{I}^{\prime}\left(\begin{array}{l}0 \\ n\end{array}\right)$ より遠くにあるが $n=500$ 以上では, $\mathrm{C}^{\prime}\left(\begin{array}{l}0 \\ x\end{array}\right)$ を中心として両側のほぼ対称 位置:両ビームが結像することになる。

III. 2. c. $\mathrm{I}_{\left(\begin{array}{c} \pm \theta \\ n\end{array}\right)}^{\prime}$ の集束

このビームは

$$
y=x \tan \theta+r\left(2-\frac{1}{n}+\tan \theta\right)
$$

で表わされ，その曲率中心 $O_{ \pm}^{\prime \prime \prime}\left(x^{\prime \prime \prime}, y^{\prime \prime \prime}\right)$ は，

$$
x^{\prime \prime \prime}=r \sin \theta, \quad y^{\prime \prime \prime}=r\left(2-\frac{1}{n}+\tan \theta-\cos \theta\right)
$$

でそれぞれのビームによる像やは，

$\mathrm{S}_{\pi / 2}^{\mathrm{I}}\left(\begin{array}{c} \pm \theta \\ n\end{array}\right)=r\left[\sin \theta+\frac{1-\left(2-t+\frac{1}{n}\right)\left(1-t+\frac{1}{n}\right)}{\sqrt{\left(2-t+\frac{1}{n}\right)\left(t+\frac{1}{n}\right)}-1}\right]$

(35)

となる。なお，記昂は前と同じである。これらの像巾
の正負，むるいは大小はやはり $\mathrm{n}$ とか $\theta$ とかによっ て変化するが， $\theta=4^{0}$ まではこれらは他のビームによ る像巾から出ないので，この範囲では問題にしなくて

\begin{tabular}{|c|c|c|c|c|}
\hline n & $1^{\circ}$ & $2^{\circ}$ & $3^{\circ}$ & $4^{\circ}$ \\
\hline \multirow{2}{*}{100} & -0.0106 & -0.0116 & -0.0140 & -0.0164 \\
\hline & 0.0100 & 0.0100 & 0.0100 & 0.0100 \\
\hline \multirow{2}{*}{500} & -0.0025 & -0.0034 & -0.0053 & -0.0078 \\
\hline & 0.0020 & 0.0020 . & 0.0020 & 0.0020 \\
\hline \multirow{2}{*}{1,000} & -0.0015 & -0.0023 & -0.0041 & -0.0067 \\
\hline & 0.0010 & 0.0010 & 0.0010 & 0.0010 \\
\hline \multirow{2}{*}{2,000} & -0.0010 & -0.0018 & -0.0037 & -0.0062 \\
\hline & 0.0005 & 0.0005 & 0.0005 & 0.0005 \\
\hline \multirow{2}{*}{5,000} & -0.0006 & -0.0015 & -0.0033 & -0.0058 \\
\hline & 0.0002 & 0.0002 & 0.0002 & 0.0002 \\
\hline$\infty$ & -0.0005 & -0.0014 & -0.0032 & -0.0056 \\
\hline
\end{tabular}

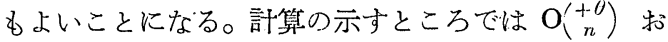
よび $\mathrm{I}\left(\begin{array}{l}0 \\ n\end{array}\right)$ がそれぞれもっとも内側におよび外側に結 像するので， $\pi / 3$ - 型のときと全く同様に総像巾は (36) 式で示される。

$$
\widetilde{S}_{\pi, 2}\left(\begin{array}{c} 
\pm \theta \\
n
\end{array}\right)=\left|\mathrm{S}_{\pi / 2}^{0}\left(\begin{array}{c}
+\theta \\
n
\end{array}\right)\right|+\mathrm{S}_{\pi / 2}^{\mathrm{I}}\left(\begin{array}{l}
0 \\
n
\end{array}\right)
$$

第 1 表 $\pi / 3$ - 型の $\subseteq$ の雨端の位置（単位 $: r$ )

第 2 表 $\frac{\pi}{2}$-型の $〕$ 両端の位置 (単位 $: r$ )

\begin{tabular}{r|r|r|r|r}
\hline \multicolumn{1}{c|}{$\theta$} & \multicolumn{1}{c|}{$1^{\circ}$} & $1^{\circ}$ & $3^{\circ}$ & $4^{\circ}$ \\
\hline \multirow{2}{*}{100} & -0.0116 & -0.0117 & -0.0137 & -0.0162 \\
& 0.1000 & 0.0100 & 0.0100 & 0.0100 \\
\hline \multirow{2}{*}{500} & -0.0024 & -0.0033 & -0.0051 & -0.0074 \\
& 0.0020 & 0.0020 & 0.0020 & 0.0020 \\
\hline \multirow{2}{*}{1,000} & -0.0015 & -0.0023 & -0.0041 & -0.0064 \\
& 0.0010 & 0.0010 & 0.0010 & 0.0010 \\
\hline \multirow{2}{*}{2,000} & -0.0010 & -0.0018 & -0.0035 & -0.0059 \\
& 0.0005 & 0.0005 & 0.0005 & 0.0005 \\
\hline \multirow{2}{*}{5,000} & -0.0007 & -0.0015 & -0.0032 & -0.0056 \\
& 0.0002 & 0.0002 & 0.0002 & 0.0002 \\
\hline$\infty$ & -0.0005 & -0.0014 & -0.0031 & -0.0053 \\
\hline
\end{tabular}

この計算結果は第 2 表に示されている。な括，表中の 符号，および総像巾の算出のしかたは第 1 表に拉ける と同じである。

\section{III .3. $\mathbf{S}_{\pi}^{\mathrm{O}, \mathrm{I}}\left(\begin{array}{l}0 \\ n\end{array}\right), \mathbf{S}_{\pi}^{\mathrm{O}, \mathrm{I}}\left(\begin{array}{c} \pm \theta \\ n\end{array}\right)$ および $\widetilde{S}_{\pi}\left(\begin{array}{c} \pm \theta \\ n\end{array}\right)$}

第 1 浪から明らかなよ5に, このばあいも，もっと も内側に結像するのは $\mathrm{O}^{( \pm \theta}\left(\begin{array}{c} \pm \\ n\end{array}\right)\left(\mathrm{O}^{\prime}\left(\begin{array}{c}+\theta \\ n\end{array}\right)\right.$ と $\mathrm{O}^{\prime}\left(\begin{array}{c}-\theta \\ n\end{array}\right)$ は 一致する）であり，もっとも外側に結像するの心 $\mathrm{I}\left(\begin{array}{l}0 \\ n\end{array}\right)$ である。 
III.3.a. $\left.\mathrm{O}_{(n}^{( \pm \theta}\right)$ の集束

$\pi / 3$ - 特よび $\pi / 2$ - 型と違ってこの 2 本のビームの 結像位置は同一で，像巾は，

$$
\Im_{\pi}^{0}\left(\begin{array}{c} 
\pm \theta \\
n
\end{array}\right)=-\left[2 r(1-\cos \theta)+\frac{r}{n}\right]
$$

である。

III. 3. b. $\mathrm{O}\left(\begin{array}{l}0 \\ n\end{array}\right), \mathrm{I}\left(\begin{array}{l}0 \\ n\end{array}\right)$ の集束

平行ビームはやはり一度交叉してからふたたび離散

し, $\mathrm{C}^{\prime}\left(\begin{array}{l}0 \\ \infty\end{array}\right)$ の両側対称位置に結像する。

$$
\mathrm{S}_{\pi}^{0}\left(\begin{array}{l}
0 \\
n
\end{array}\right)=-\frac{r}{n}, \quad \mathrm{~S}_{\pi}^{\mathrm{I}}\left(\begin{array}{l}
0 \\
n
\end{array}\right)=\frac{r}{n}
$$

それゆえに，

$$
\mathfrak{S}_{\pi}^{\mathrm{O}, \mathrm{I}}\left(\begin{array}{l}
0 \\
n
\end{array}\right)=\frac{2 r}{n} \quad(\text { ビームの厚み })
$$

となる。

III. 3. c. $\mathrm{I}\left(\begin{array}{c} \pm \theta \\ n\end{array}\right)$ の集束

この 2 本のビームも同一点に結像し，像巾は，

$$
\widetilde{S}_{\pi}^{\mathrm{I}}\left(\begin{array}{c} 
\pm \theta \\
n
\end{array}\right)=-\left[2 r(1-\cos \theta)-\frac{r}{n}\right] \quad(40)
$$

であり，結局総像巾は

$$
\Im_{\pi}\left(\begin{array}{l} 
\pm \theta \\
n
\end{array}\right)=2 r(1-\cos \theta)+\frac{2 r}{n}
$$

すなわち，ビームの厚みだけ像巾が増加することにな る。

\section{IV. 結 論}

1. 一次単集束型の質量分析計設計上の知見を得る。
ために, $\pi / 3-\pi / 2-$ および $\pi$ 型のそれぞれについて, コレクター上に得られる像巾を幾何学的方法で計算し た。

2. イオン・ビームに厚みがなくてひろがりのみの あるばあいには，収差は $+\theta$ の侧では $\pi / 3>\pi / 2>\pi$ の順で大きく，- $\theta$ の側では $\pi>\pi / 2>\pi / 3$ の順で大 きいことを認めた。

3. イオン・ビームに厚みもひろがりもあるばあい には, $\pi / 3$ - 型と $\pi / 2$ 一型とについては収差は大差な $く, \pi$ 型が前二者に比して有利であることが浔めら れた。

4. また総像巾をスリットウと偏向半径の比の函数 として計算しイオン源出ロスリット設計上の知見を得 た。

文献

(1) W. Heuneberg, Ann. d. Physik, 19, 335 (1934).

(2) R. Herzog, Z. f. Physik, 89, 447 (1934).

(3) J, Mattauch. ibid., 89, 786 (1934).

(4) L. Kerwin. Rev. Sci. Instr., 20, 36 ; 381 (1949).

(5) 質量分析, 10, 85 (1958).

(6) N. F. Barber, Proc. Leeds Philos. Soc., 2, 427 (1933).

\section{質量スペクトルにおける温度の影響について}

\section{Effect of Temperature on Mass Spectra}

岡本潤一*.角田 実*·森戸 望*.中島康雄*

Junichi Okamoto, Minoru Kakuta, Nozomu Morito, Yasuo Nakajima

（昭和33年 9 月 4 日受理）

質量分析計に打いて質量スペクトルの満足な再現性をろることはいずれの仕事に分析計が用いられても根本的に重要な

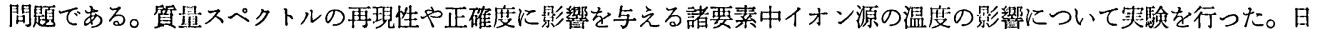
立製 RMU-5 型質量分析計に T 型イオン源を取付け，イオン源を所定の $250^{\circ} \mathrm{C}$ に保った際のイオン源の温度分布，ま たイオン源の温度を $170 〜 290^{\circ} \mathrm{C}$ に变化した時のパタン係数扣よび感度の变動を測定した。精密級質量分析計ではパタン 係数打よび感度の安定性の変動率は一般にそれぞれ 士0.5\%，士1\% 以内とされている。この要求を満足するにはイオン 源の温度を $250^{\circ} \mathrm{C}$ に拈いて $\pm 0.25^{\circ} \mathrm{C}$ に保たねばならないことがわかった。

\section{〔I〕緒言}

質量分析法は元来同位体存在比の測定によって発達

* 日立製作所中央研究所（東京都北多摩郡国分寺町）

Hitachi Central Research Laboratory (Kokubunji-machi, Kitatama-gun, Tokyo).
した物理的分析法であるが，今日では化合物の解離電 離等の基磷的研究のみならず広く工業方面に応用され るようになった。研究用精密質量分析計またはパタン 係数の複雑な炭化水素を分析するための質量分析計を 設計するにあたっては種種の間題について考葸されな ければならない。すなわち広範囲にわたる走査，高分 